\title{
MENINGKATKAN KEAKTIFAN SISWA PADA PEMBELAJARAN SEJARAH MELALUI PENERAPAN MODEL JIGSAW PLUS PADA SISWA KELAS XII IPS 3 SMAN 1 SELONG TAHUN PEMBELAJARAN 2017/2018
}

\author{
${ }^{1}$ Haerudin \\ ${ }^{1}$ SMAN 1 Selong \\ haerudin@gmail.com
}

\begin{abstract}
Abstrak
Keberadaan pendidikan mata pelajaran sejarah memiliki peran strategis dalam mewujudkan tujuan pendidkan nasional. Namundalam tataran implementasi, konsepsi ideal tersebut masih banyak menemui kendala. Kecendrungannya, pembelajaran sejarah pada saat-saat tertentu dan pada kelas-kelas tertentu kurang menggembirakan. Ketika pembelajaran sejarah mengedepankan model ataupun metode pembelajaran yang monoton, seringkali berbagai permasalahan muncul. Suasana kelas menjadi kurang dinamis dan siswa sangat pasif serta terasa bahwa guru seperti mengajar beberapa orang saja. Munculnya berbagai pemasalahan seperti di sebutkan di atas menginspirasi peneliti mengkaji salah satu model atau metode dalam pembelajaran sejarah yang disebut dengan model Jigsaw Plus.Tujuan penelitian ini adalah untuk mengetahui peningkatkan keaktifan siswa dalam pembelajaran sejarah materi orde reformsimelalui penerapan model Jigsaw Plus pada siwa kelas XII IPS 3 SMA Negeri 1 Selong tahun pembelajaran 2017/2018. Jenis penelitian ini termasuk Penelitian Tindakan Kelas (PTK), dilaksanakan di kelas XII IPS 3 SMA Negeri 1 Selong, waktu pelaksanaan pada bulan Januari sampai dengan bulan Maret 2018dengan subyek penelitian sebanyak 33 orang siswa. Faktor yang diselidiki meliputi faktor siswa dan faktor guru, Instrumen penelitian menggunakan lembar observasi dan tes, serta teknik analisis data menggunakan teknik analisis kualitatif. Hasil penelitian menunjukkan bahwa penerapan model Jigsaw Plus dalam pembelajaran Masa Orde Reformasi telah berhasil meningkatkan keaktifan siswa kelas XII IPS 3 SMA Negeri 1 Selong tahun pembelajaran 2017/2018
\end{abstract}

Kata Kunci: Jigsaw Plus, Keaktifan Siswa

\section{PENDAHULUAN}

Keberadaan pendidikan mata pelajaran sejarah dalam kegiatan pembelajaran memiliki peran penting dan strategis dalam mewujudkan tujuan pendidkan nasional. Karena itu, guru sejarah sebagai pelaku pembelajaran harus melatih keterampilan sosial siswa melaui berbagai strategi ataupun metode pembelajaran. Mereka harus sadar bahwa mereka tidak hanya berfungsi mentransfer ilmu pengetahuan kepada siswa dan mengajak siswa untuk belajar, melainkan juga mendidik siswa untuk " Bagaimana belajar untuk belajar ".Dengan konsep yang demikian, diharapkan siswa tidak hanya 
Fajar Historia

Volume 2 Nomor 1, Juni 2018, hal. 70-88

dijadikan sebagai objek pembelajaran, tetapi juga sebagai subjek pembelajaran. Mereka diharapkan dapat berintraksi secara wajar dengan lebih banyak berperan secara aktif 
dalam proses pembelajaran (Silberman, 2004). Mereka dapat menemukan sendiri kekuatan-kekuatan terpendam yang ada yang ada pada diri mereka.

Dalam kenyataannya, konsep ideal tidak selalu sejalan dengan fakta di lapangan. Berdasarkan pengalaman selama menjadi guru di SMA Negeri 1 Selong, ada kecendrungaan pembelajaran sejarah pada saat-saat tertentu dan pada kelas-kelas tertentu kurang menggembirakan. Satu hal yang pasti bahwa ketika pembelajaran sejarah lebih banyak menggunakan metode-metode konvensional seperti metode ceramah, seringkali berbagai permasalahan secara kasat mata semakin nampak. Beberapa indikator menunjukkan bahwa selama proses pembelajaran, siswa yang memiliki kreatifitas dalam bertanya maupun mengemukakan pendapat sangat minim . Suasana kelas menjadi kurang dinamis dan siswa sangat pasif serta terasa bahwa guru seperti mengajar beberapa orang saja.

Hasil observasi awal menunjukkan bahwa munculnya berbagai masalah seperti yang terungkap di atas, diprediksi lebih banyak disebabkan oleh masalah strategi ataupun metode pembelajaran yang diterapkan. Penerapan strategi atau metode pembelajaran yang bersifat monoton dan mengarah pada dominasi guru seringkali menyebabkan kurangnya kesempatan bagi siswa untuk berperan dalam pembelajaran. Karena kurangnya kesempatan untuk berperan, maka ruang gerak siswa untuk menonjolkan kreatiftasnya juga menjadi berkurang. Akibatnya, muncullah keengganan siswa untuk berperan secara aktif dalam kegiatan pembelajaran.

Mencermati berbagai permasalahan sebagaimana disebutkan diatas, sudah sepatutnnya kajian tentang penerapan berbagai strategi maupun metode pembelajaran yang lebih variatif dan inovatif perlu digalakkan. Adanya berbagai tantangan berat yang harus dihadapi oleh guru dikelas, menuntut para guru sejarah harus dapat menyajikan sejarah secara lebih meyakinkan, menarik, inovatif dan kreatif, sehingga siswa dapat meningkatkan peran serta dan keaktifannya dalam mengikuti setiap kegiatan pembelajaran.

Penerapan model Jigsaw Plusdapat menjadi salah satu alternatif dalam mengatasi persoalan di atas. Model Jigsaw dikembangkan oleh Elliot Aronson, dan rekan-rekannya (dalam Slavin, 2005). Melalui metode Cooperative Learning model Jigsaw, kelas dibagi menjadi beberapa kelompok yang anggotanya terdiri dari 4-5 siswa dengan karakteristik 
yang heterogen. Kelompok ini disebut dengan kelompok asal atau kelompok awal (home group). Tugas dibagikan pada tiap kelompok asal, dan setiap anggota mendapat tugas masing-masing yang berbeda. Para anggota kelompok asal yang berbeda memiliki tanggung jawab untuk mengkaji tugasnya masing-masing dan berkumpul dengan anggota kelompok asal lainnya dengan tugas yang sama. Kelompok ini dinamakan kelmpok ahli atau kelompok pakar (expert group). Selanjutnya para siswa yang berada dalam kelompok ahli kembali ke keolmpok asal untuk mengajar anggota lainnya mengenai materi yang telah dipelajari dalam kelompok ahli.

Adapun Model Jigsaw plus yang dimaksudkan dalam penelitian ini terkait dengan penambahan aktifitas atau kegiatan dalam menerapkan model jigsaw yang ada. Secara umum tahapan kegiatan yang dilakukan tetap mengacu pada langkah-langkahJigsaw, tetapi di tambah langkah-langkah kegiatan pada tahapan awal dan akhir kegiatan. Ada modifikasi berkaitan dengan formasi pembentukan kelompok besar dan kecil yang disebut sebagai kelompok utama dan adanya kegiatan presentasi oleh kelompok utama pada akhir pembelajaran.Jadi ada tiga kelompok yang terbentuk dalam hal ini yaitu 1)kelompok utama, 2)kelompok asal, dan 3)kelompok ahli. Adapun langkah-langkah pembelajaran dengan menggunakan metode model Jigsaw Plus sebagai berikut :

Pada tahap pertama, kelas dibagi menjadi dua kelompok besar yaitu kelompok A dan kelompok B. Kelompok ini kemudian dinamakan kelompok utama

Kelompok A dan B dibagi lagi ke dalam kelompok kecil yang beranggotakan 4-5 orang. Kelompok ini dinamakan dengan kelompok asal

Guru membagikan tugas kepada masing masaing kelompok sesuai dengan nomor urut siswa dalam kelompok (tugas untuk kelompok A dan B berbeda) dan masingmasing siswa dalam kelompok mendapatkan tugas yang berbeda

Masing-masing siswa yang memiliki nomor urut yang sama dari setiap kelompok asal membuat kelompok baru (Kelompok ahli) untuk mendiskusikan tugas yang mereka dapatkan.Setelah mereka selesai berdiskusi dalam kelompok ahli, mereka kembali ke kelompok asal untuk saling menjelaskan kepada kelompoknya hasil diskusi dari kelompok ahli. Apabila kelompok sudah menyelesaikan tugasnya, secara keseluruhan masing-masing ketua kelompok asal kembali ke kelompok utama untuk membuat 
resume bahan presentasi sekaligus menentukan wakil mereka untuk maju mempresentasikan hasil kelompoknya.

Rumusan masalah yang diajukan dalam penelitian ini adalah:Bagaimanakah peningkatkan keaktifan siswa pada pembelajaran sejarah materi orde reformasi dalam Penerapan Model Jigsaw Plussiwa kelas XII IPS 3 SMA Negeri 1 Selong tahun pembelajaran 2017/2018. Tujuan penelitian ini adalah untuk mengetahui peningkatkan keaktifan siswa dalam pembelajaran sejarah materi orde reformsimelalui penerapan model Jigsaw Plus pada siwa kelas XII IPS 3 SMA Negeri 1 Selong tahun pembelajaran 2017/2018

\section{METODE PENELITIAN}

Penelitian ini dilaksanakan di kelas XII IPS 3 SMA Negeri 1 Selong. Adapun pertimbangan dipilihnya kelas XII IPS3 didasarkan hasil observasi pendahuluan dan hasil diskusi terbatas dengan beberapa rekan guru yang juga mengajar di kelas XII IPS 3. Secara umum mereka berpendapat bahwa diantara kelas yang paling rendah tingkat partisipasi atau keaktifan dalam setiap proses pembelajaran adalah kelas XII IPS3. Jumlah siswa yang menjadi subyek penelitian sebanyak 33 orang, terdiri dari 14 orang laki-laki dan 19 orang perempuan. SMA Negeri 1 Selong berlokasi di Jalan TGH. Umar No 03 Selong Kabupaten Lombok Timur, Propinsi Nusa Tenggara Barat. Pelaksanaan penlitian ini melibatkan satu orang guru sebagai peneliti dan dua orang sebagai pengamat/observer.

Penelitian ini dilkasanakan 3 bulan yaitu dari bulan Januari sampai dengan bulan Maret 2018 atau pada semester genap tahun pelajaran 2017 / 2018. Penelitian ini termasuk dalam penelitian classroom Action Research/ penelitian Tindakan Kelas. Pelaksanaannya direncanakan dalam bentuk implementasi rancangan pembelajaran yang disajikan melalui beberapa siklus. Setiap siklus terdiri dari 4 rangkaian kegiatan yaitu 1) perencanaan, 2) pelaksanaan/tindakan, 3) observasi dan 4)refleksi. Kegiatan ini dilaksanakan secara simultan dan disesuaikan dengan perubahan yang terjadi pada tiap siklus sampai pada akhirnya dicapai hasil yang ideal / yang seharusnya. Instrumen yang digunakan dalam penelitian ini adalah observasi / pengamatan. 
Data yang terkumpul dalam penelitian ini dianalisis dengan analisis kualitatif dengan mengacu pada model analisis interaktif yaitu interaksi dari ketiga komponen utama. Tiga komponen utama tersebut menurut Miles dan Huberman (1992), yaitu "Reduksi data, paparan data, dan penarikan kesimpulan". Berdasarkan data yang telah terkumpul, maka dilakukan analisis dan refleksi terhadap hasil dan proses tindakan yang telah dilakukan. Analisis tersebut dilakukan dengan cara membandingkan hasil tindakan dengan indikator kinerja yang diterapkan. Jika hasil tindakan lebih baik atau sama dengan indikator yang telah diterapkan, maka penelitian tindakan kelas ini dinilai berhasil. Jika hasilnya lebih rendah atau lebih jelek, maka penelitian tindakan ini ditetapkan belum berhasil, dan selanjutnya dilakukan perbaikan ulang dalam siklus kegiatan kedua dan seterusnya sampai tindakan berhasil.

\section{HASIL PENELITIAN DAN PEMBAHASAN}

\section{Hasil Penelitian}

Analisis data penelitian Siklus I

Pelaksanaan

Kegiatan pembelajaran pada siklus I membahas materi pembelajaran Orde Reformasi sub materi : Awal reformasi/pemerintahan B.J Habibie. Kegiatan ini dilaksanakan hari selasa tanggal 30 Januari 2018 tahun pelajaran 2017/2018, berlangsung selama 2X 45 menit ( $1 \mathrm{X}$ pertemuan )

\section{Data Hasil Observasi}

1). Data Hasil observasi kegiatan siswa

Hasil pengamatan observer terhadap tingkat keaktifan siswa pada awal-awal pembelajaran sebenarnya cukup baik. Ketika guru membuat kelompok utama dengan membagi kelas menjadi dua kelompok besar, respon siswa cukup baik. Begitu pula ketika pembentukan kelompok asal sampai pada tahapan distribusi tugas yang diikuti dengan diskusi pada kelompok ahli, nampaknya para anggota kelompok cukup antusiaas. Kondisi kelas mulai agak kurang kondusif ketika mereka melakukan kegiatan diskusi pada kelompok asal dan presentasi kelompok utama. Beberapa siswa mulai keluar masuk ruangan / kelas. Keaktifan siswa dalam kegiatan diskusi di kelompok asal masih rendah. Beberapa siswa belum mampu menyampaikan hasil 
diskusinya di kelompok ahli kepada rekannya dikelompok asal secara baik. Suasana kelaspun sedikit agak gaduh. Pada tahap presentasi, kegiatan tanya jawab intensitasnya sangat rendah, kelihatan kelompok juga sangat kaku, tingkat keaktifan dalam mengajukan pertanyaan atau jawaban juga sangat rendah serta nampak bahwa beberapa pertanyaan maupun ulasan bersifat teks book

2) Data hasil observasi kegiatan guru

Berdasarkan hasil observasi terhadap kegiatan guru dalam pelaksanaan pembelajaran, dapat diuraikan beberapa hal sebagai berikut :

Guru secara prosedural pada dasarnya telah melaksanakan kegiatan pembelajaran sesuai dengan skenario pembelajaran yang telah dirancang sebelumnya. Pemamfaatan waktu juga cukup epektif. Hanya saja ada beberapa hal yang masih kurang mendapat penekanan sehingga dalam melaksanakan peran dan fungsinya sebagai fasilitator dan motivator nampak kaku. Pemberian motivasi oleh guru juga masih kurang sehingga nampak siswa kurang bersemangat dalam kegiatan pembelajaran; khususnya pada tahapan diskusi kelompok asal dan presentasi kelompok utama. Guru masih terlalu terpaku dengan rangkaian-rangkaian kegiatan dan relatif kurang memperhatikan masalah yang dihadapi oleh siswa.

2). Data Prestasi Belajar Siswa

Berdasarkan hasil evaluasi terhadap pelaksanaan pembelajaran sebagaimana terlampir dalam lampiran 02, maka berikut ini disajikan ringkasan Prestasi belajar siswa pada siklus I sebagai berikut :

Nilai rata rata kelas adalah 77,42

Siswa yang tuntas belajar secara indiviidual sebanyak 29 orang

Persentase ketuntasan adalah $87,87 \%$

Jika dihubungkan dengan indikator keberhasilan, maka Angka 87,87 \% menunjukkan masih adanya siswa yang belum tuntas yakni sebanyak 4 dari 33 orang siswa atau sebesar $12.12 \%$.

Refleksi

Munculnya berbagai masalah dalam pelaksanaan pembelajaran pada siklus I ini berdasarkan hasil catatan dan diskusi dengan observer, masukan dari siswa maupun apa yang dialami oleh peneliti, dapat direfleksikan beberapa hal sebagai berikut : 
Kesiapan siswa dalam mengikuti pembelajaran dengan menggunakan model JigsawPlusmasih kurang disebabkan siswa kurang terbiasa atau merasa kaku dengan prosedur-prosedur yang dianggap agak berbelit-belit. Dalam konteks ini, faktor sosialisasi terhadap aturan main dalam kegiatan diskusi menjadi hal yang penting untuk diperhatikan. Guru perlu mempersiapkan diri lebih baik sehingga penyampaian aturan main dapat dikomunikasikan dengan bahasa yang sederhana dan tidak bias (terarah).

Siswa kurang bersemangat dalam mengikuti pembelajaran khususnya diakhir-akhir pembelajaran.

Munculnya keadaan ini disamping karena faktor di atas, juga karena guru tidak banyak memberikan motivasi yang mampu membangkitkan antusiasme siswa dalam mengikuti kegiatan. Guru dalam hal ini kurang memberikan dorongan kepada siswa yang kurang aktif ataupun penghargaan bagi siswa yang aktif. Dalam posisi ini siswa merasa bahwa tidak ada perbedaan antara siswa yang aktif dan siswa yang kurang aktif. Karena itu dibutuhkan perhatian dan dorongan yang seksama dari guru terhadap setiap aktifitas siswa sehingga siswa merasa diperhatikan dan dihargai oleh gurunya. Guru juga perlu melakukan pendekatan persuasif secara idividual khususnya terhadap siswa yang kurang aktif.

Pada siklus I, komunikasi dan kerjasama siswa dalam kelompok nampak kurang. Siswa yang berkemampuan tinggi kurang mau bekerjasama dengan temannya yang berkemampuan rendah, dan siswa yang berkemampuan rendah enggan berkonsulidasi dengan teman yang berkemampuan lebih tinggi. Untuk itu diperlukan pemahaman oleh siswa tentang hakekat hidup berkelompok. Guru perlu menekankan bahwa keberhasilan kelompok tidak ditentukan oleh seorang yang berkemampuan tinggi saja, melainkan sinergi antar berbagai potensi yang dimiliki oleh masing-masing individu dalam kelompok tersebut. Berdasarkan analisa terhadap berbagai masalah yang ditemukan pada siklus I sebagaiman disebutkan di atas, maka dirumuskan beberapa alternatif rencana tindakan baru dalam pelaksanaan siklus II, sebagai berikut :

Kurangnya tingkat pemahaman siswa terhadap aturan main metode dan model pembelajaran yang diterapkan ternyata berpengaruh terhadap kelancaran kegiatan pembelajaran. Oleh karena itu sebelum kegiatan pembentukan kelompok dan pendistribusian tugas berlangsung, guru sekali lagi menjelaskan kepada siswa 
alur/langkah-langkah kegiatan yang akan ditempuh dalam pelaksanaan diskusi tersebut. Dengan adanya pengalaman pada pelaksanaan siklus I ditambah dengan penjelasan tambahan tentang aturan main tersebut, diharapkan bahwa pada siklus II, siswa tidak lagi terbeban dengan hal-hal yang bersifat teknis dan dapat mempokuskan diri pada halhal yang bersifat substansial.

Motivasi siswa yang rendah pada siklus I, antara lain disebabkan karena mereka kurang terbiasa, kurang berani atau kurang percaya diri. Disamping itu, mereka merasa kurang diperhatikan atau dihargai oleh guru, meskipun sebenarnya guru sudah merasa memperhatikan hal tersebut. Dalam konteks ini diperlukan tindakan yang lebih nyata dari guru dalam memberikan reward bagi siswa yang dianggap aktif dan bimbingan individual secara langsung kepada siswa yang dianggap kurang berani atau kurang aktif . Beberapa tindakan nyata yang dapat dilakukan oleh guru dalam hal ini antara lain, pemberian penghargaan berupa aplous atau acungan jempol kepada kelompok yang paling cepat menyelesaiakan tugasnya, kelompok yang maju atau terhadap pertanyaan ataupun jawaban yang diajukan oleh anggota kelompok.

Melakukan pendekatan atau koordinasi kepada kelompok, khususnya kelompokkelompok yang berpoptensi memiliki masalah untuk dapat memberikan bimbingan secara langsung. Jadi guru tidak terpaku di belakang meja.

\section{Analisis data penelitian Siklus II}

Pelaksanaan

Kegiatan pembelajaran pada siklus II membahas materi tentang Masa Orde Reformasi (sub materi: Masa pemerintahan Abdurrahman Wahid dan Megawati). Dilaksanakan pada hari selasa tanggal 13 Februari 2018 berlangsung selama 2X 45 menit ( $1 \mathrm{X}$ pertemuan )

Data Hasil Observasi

1). Data Hasil observasi kegiatan siswa

Kegiatan siswa pada siklus II dalam beberapa hal sudah menunjukakan peningkatan yang cukup berarti. Setelah guru kembali melakukan sosialisasi secara singkat berkaitan dengan aturan main, memberikan dorongan/penghargaan kepada individu atau kelompok yang aktif dan bimbingan secara langsung kepada kelompok 
yang dianggap bermasalah, maka beberapa hal yang dianggap sebagai masalah pada siklus I secara umum telah berhasil diatasi. siswa telah menunjukkan keseriusannya dalam proses pembelajaran. Tingkat keaktifan masing-masing individu dalam kelompok baik pada saat diskusi di kelompok ahli maupun diskusi di kelompok asal sangat tinggi. Tidak terlihat lagi siswa yang lalu lalang tanpa tujuan yang jelas serta waktu yang digunakan oleh masing-masing kelompok sesuai dengan waktu yang sudah ditargetkan. Semangat persaingan antar kelompok sudah nampak sangat baik khususnya ketika berlangsung presentasi oleh kelompok utama. Hal ini terlihat dari banyaknya pertanyaan yang diajukan baik oleh kelompok utama A maupun kelompok utama B.Meraka sebagian besar sudah dapat bekerja sesuai dengan peran dan fungsinya masing-masing dalam kelompok.

Hal yang nampak masih kurang pada tahapan ini adalah belum tuntasnya secara optimal bimbingan kepada individu yang dianggap bermaslah serta kualitas pertanyaan yang masih rendah. Sebagian besar pertanyaan yang muncul pada sesi tanya jawab masih bersifat teks book/hapalan. Dari pertanyaan yang teridentifikasi, sekitar $50 \%$ masih bersifat hafalan.

2). Data hasil observasi kegiatan guru

Berdasarkan hasil observasi terhadap kegiatan guru dalam pelaksanaan pembelajaran, dapat diuraikan beberapa hal sebagai berikut :

Pelaksanaan pembelajaran yang dipimpin oleh guru sebenarnya telah terlaksana sesuai dengan rencana yang telah disiapkan. Guru telah berusaha mengimplementasikan kegiatan pembelajaran sesuai dengan skenario pembelajaran yang telah dirancang sebelumnya. Guru telah mensosialisasikan aturan main kepada siswa secara efektif dan efisien. Pemberian reward dan bimbingan langsung kepada individu maupun kelompok telah dilakukan. Meskipun demikian, beberapa aktifitas yang dilakukan oleh guru masih menunjukkan beberapa kelemahan, diantaranya sikap kaku dan masih kurang efektifnya pendekatan / bimbingan individu yang dilakukan oleh guru.

2). Data Prestasi Belajar Siswa

Berdasarkan hasil evaluasi terhadap pelaksanaan pembelajaran disajikan ringkasan prestasi belajar siswa pada siklus II sebagai berikut :

Nilai rata rata kelas adalah 81,21 
Siswa yang tuntas belajar secara indiviidual sebanyak 32 orang

Ketuntasan belajar secara adalah $96.96 \%$

Jika dihubungkan dengan indikator keberhasilan, maka nilai rata rata kelas yang dicapai oleh siswa pada siklus II pada dasarnya telah terjadi peningkatan yang cukup berarti yaitu dari 77.42 menjadi 81,21. Persentase ketuntasan juga meningkat menjadi 32 orang dari jumlah siswa sebanyak 33 orang .Begitu pula halnya dengan tingkat ketuntasan belajar yang menunjukkan tingkat keberhasilan yang cukup berarti yaitu dari angka dari 87.87\% menjadi $96.96 \%$. menunjukkan adanya indikasi keberhasilan dari pelaksanaan perbaikan / tindakan baru yang telah dilaksanakan. Hanya saja, angkaangka di atas masih belum memenuhi indikator kinerja sebagaimana ditetapkan sebelumnya, sehingga perlu terus dilanjutkan.

Refleksi

Berdasarkan hasil catatan dan diskusi dengan observer, masukan dari siswa maupun apa yang dialami oleh peneliti, maka pelaksanaan penelitian pada siklus II ini dapat direfleksikan beberapa hal sebagai berikut :

1). Hal-hal yang telah berhasil dilaksanakan :

a) Proses pembelajaran yang telah dilakukan oleh guru pada siklus II ini secara umum telah dapat dilaksanakan sesuai dengan rencana / skenario pembelajaran. Tindakan-tindakan baru sebagai perbaikan dari tindakan sebelumnya telah menujukkan hasil yang sangat positif.

b) Penjelasan ulang terhadap berbagai aturan main/langkah-langkah kegiatan yang harus dilakukan dalam pelaksanaan diskusi baikdikelompok asal, kelompok ahli maupun kelompok utama telah dapat dilaksanakan dengan efektif dan efisien.

c) Pemberian bimbingan dan pemberian reward kepada individiu maupun kelompok secara langsung pada saat mereka menyelesaikan tugas di kelompok asal dan kepada individu maupun kelompok ketika berlangsung presentasi telah mampu membangkitkan semangat atau motivasi sebagian besar siswa dalam kegiatan pembelajaran. Siswa merasa diperhatikan dan dihargai oleh guru, sehingga tidak terlihat lagi adanya siswa yang keluar masuk kelas tanpa tujuan jelas.

2). Hal-hal yang masih belum terlaksana dengan baik 
a) Pemberian bimbingan individu kepada siswa yang dianggap menemui berbagai permasalahan belum dapat terlaksana secara oftimal.

b) Pertanyaan pertanyaan yang diajukan sebagian besar masih bersifat teks book/hafalan. .

Mengacu pada hasil evaluasi dan refleksi terhadap kegiatan pembelajaran pada siklus II ini maka disimpulkan bahwa kegiatan pada siklus II ini belum memenuhi indikator kinerja yang telah ditetapkan. Karena itu kegiatan penelitian ini perlu dilanjutkan pada siklus III untuk menerapkan tindakan-tindakan baru sebagai perbaikan terhadap berbagai kelemahan yang muncul pada siklus II. Selanjutnya, berdasarkan adanya berbagai kelemahan yang nampak sebagaimana disebutkan di atas mengharuskan guru memfokuskan diri terhadap berbagai permasalahan tersebut. Hal yang harus dilakukan dalam hal ini dapat dimulai dengan menganalisa penyebab munculnya masalah tersebut, sehingga alternatif yang perbaikan yang dilakukan sesuai dengan akar permasalahannya. Berdasarkan hasil analisa yang dilakukan maka pada siklus III, direncanakan tindaka-tindakan baru sebagai berikut :

1) Untuk masalah I, guru harus kemabali memfokuskan bimbingannya secara individual kepada anggota kelompok yang diidentifikasi bermasalah.

2) Untuk menagatasi masalah kualitas pertanyaan yang masih rendah, guru nampaknya perlu memberikan penjelasan dan contoh kepada siswa bagaimana menganalisa materi dan menyampaikan pertanyaan-pertanyaan yang tidak bersifat hafalan. (pertanyaan pengembangan). Dalam kegiatan ini guru perlu lebih selektif dan hati-hati dalam memberikan penjelasan agar disatu sisi semangat yang sudah mulai nampak dapat terjaga, dan dilain pihak dapat memacu siswa untuk mengajukan pertanyaan yang lebih berkualitas.

Analisis data hasil penelitian siklus III

a. Pelaksanaan

Kegiatan pembelajaran pada siklus III membahas materi Orde reformasi, sub Masa Pemerintahan SBY dan Jokowi. Dilaksanakan pada hari selasa tanggal 27 Februari tahun 2018, berlangsung selama 2X 45 menit (1 X pertemuan) 
Proses pembelajaran pada siklus III ini merupakan kelanjutan dari pelaksanaan tindakan pada siklus II dengan beberapa tindakan baru sesuai dengan analisa hasil observasi dan refleksi pada siklus II. Pada tahap perencanaan, telah disepakati bahwa tindakantindakan baru yang akan dilaksanakan pada siklus III difokuskan pada pemantapan terhadap tindakan-tindakan yang sebelumnya dianggap telah baik dan pelaksanaan tindakan-tindakan baru seperti bimbingan individu kepada beberapa siswa yang diidentifikasi bermasalah dan pemberian penjelasan dan contoh kepada siswa berkaitan dengan bagaimana menganalisa materi dan menyampaikan pertanyaan-pertanyaan yang tidak bersifat hafalan/teks books.

b. Data Hasil Observasi

1) Data Hasil observasi kegiatan siswa

Hasil catatan observer terhadap kegiatan siswa pada siklus III juga sudah cukup baik. Siswa telah menunjukkan keseriusannya dalam mengikuti pembelajaran. Tingkat keaktifan setiap individu dalam menyelesaikan tugas maupun dalam kegiatan diskusi disetiap level kelompok sudah berjalan dengan baik.bahkan sesekali siswa yang merasa meiliki permasalahan sudah dengan kesadaran sendiri meminta bimbingan kepada guru berkaitan dengan permasalahan yang dihadapi. Semangat persaingan antar kelompok sudah nampak, terlihat dari banyaknya pertanyaan yang diajukan oleh masing-masing kelompok ke kelompok lainnya. Meskipun masih ada sebagian pertanyaan yang bersifat hapalan, tetapi secara umum kualitas pertanyaan sudah cukup baik. Tidak nampak lagi adanya siswa yang keluar masuk kelas. Meraka sudah dapat bekerja sesuai dengan peran dan fungsinya masing-masing dalam kelompok.

2). Data hasil observasi kegiatan guru

Berdasarkan hasil observasi terhadap kegiatan guru dalam pelaksanaan pembelajaran, dapat diuraikan beberapa hal sebagai berikut :

Pelaksanaan pembelajaran yang dipimpin oleh guru telah terlaksana sesuai dengan rencana yang telah disiapkan. Guru telah mampu mengimplementasikan kegiatan pembelajaran sesuai dengan skenario pembelajaran yang telah dirancang sebelumnya. Guru telah mampu mensosialisasikan aturan main kepada siswa secara efektif dan efisien. Pemberian reward dan bimbingan langsumg kepada individu maupun kelompok telah dapat dilakukan secara baik. Begitu Pula halnya dengan arahan tentang koordinasi 
antar anggota dalam kelompok-kelompok diskusi telah dapat dilaksanakan dengan baik. Kreatifitas guru dalam menumbuhkan motivasi siswa sudah menunjukkan adanya peningkatan yang berarti.

\section{3). Data Prestasi Belajar Siswa}

Berdasarkan hasil evaluasi terhadap pelaksanaan pembelajaran, maka berikut ini disajikan ringkasan Prestasi belajar siswa pada siklus III sebagai berikut:

1). Nilai rata rata kelas adalah 85,45

2). Siswa yang tuntas belajar sebanyak 33 orang atau $100 \%$

Jika dihubungkan dengan indikator keberhasilan, maka nilai rata rata kelas yang dicapai oleh siswa pada siklus III telah terjadi peningkatan yang cukup berarti yaitu dari 81,21 menjadi 85,45.Sementara itu, persentase ketuntasan juga mencapai $100 \%$.

\section{Refleksi}

Mencermati hasil catatan dan diskusi dengan observer, masukan dari siswa maupun apa yang dialami oleh peneliti, maka pelaksanaan penelitian pada siklus III ini dapat direfleksikan beberapa hal sebagai berikut :

1) Proses pembelajaran yang telah dilakukan oleh guru pada siklus III ini telah dapat dilaksanakan sesuai dengan rencana/skenario pembelajaran. Tindakantindakan baru sebagai perbaikan dari tindakan sebelumnya telah dapat dilaksanakan secara optimal.

2) Penjelasan ulang terhadap berbagai aturan main/langkah-langkah kegiatan yang harus dilakukan dapat dilaksanakan dengan efektif dan efisien.

3) Pemberian bimbingan kepada individiu maupun kelompok-kelompok secara langsung dan pemberian reward kepada individu maupun kelompok ketika berlangsung presentasi telah mampu membangkitkan semangat atau motivasi siswa dalam kegiatan pembelajaran. Siswa merasa diperhatikan dan dihargai oleh guru, sehingga tidak terlihat lagi adanya siswa yang keluar masuk kelas tanpa tujuan jelas.

4) Pemberian arahan tentang pembagian kerja dalam kelompok-kelompok kecil ketika mendiskuskan tugas telah mampu meningkatkan partisipasi setiap individu sesuai dengan peran/tanggung jawab masing-masing. 
Dengan demikian, kegiatan ini dianggap sudah cukup untuk dapat menyatakan bahwa kegiatan diskusi kelompok kecil yang dilkukan oleh siswa mampu meningkatkan nilai rata-rata siwa dalam pembelajaran Sejarah. Karena itu kegiatan penelitian ini dicukupkan sampai siklus III.

\section{Pembahasan}

Dari hasil penelitian pada siklus I diperoleh hasil yang menunjukkan bahwa pelaksanaan tindakan belum memenuhi indikator kinerja yang ditetapkan. Hal ini ditunjukkan dengan hasil observasi dan evaluasi terhadap tingkat keaktifan siswa dan pelaksanaan skenario pembelajaran yang dilaksanakan oleh guru. Rendahnya tingkat keaktifan siswa dalam mengikuti proses pembelajaran pada siklus I ini berkaitan erat dengan terdapatnya berbagai kelemahan pada saat pelaksanaan skenario pembelajaran. Rendahnya tingkat keaktifan siswa yang disebabkan oleh munculnya berbagai kelemahan dalam pelaksanaan skenario pembelajaran pada akhirnya juga berdampak terhadap rendahnya tingkat prestasi siswa.

Analisa terhadap hasil observasi pelaksanaan tindakan menunjukkan bahwa beberapa hal yang cukup substansial dianggap sebagai pemicu terjadinya hasil yang kurang memuaskan tersebut antara lain: rendahnya tingkat kemampuan guru dalam membangkitkan motivasi belajar siswa, kurang jelas dan terarahnya guru dalam menyampaiklan aturan main/langkah-langkah yang harus ditempuh dalam kegiatan diskusi,dan kurang tanggapnya guru terhadap masalah yang dihadapi oleh siswa. Akibatnya siswa nampak sangat kaku dalam melakukan berbagai aktifitas pembelajaran yang berujung pada rendahnya tingkat keaktifan mereka dalam mengikuti kegiatan pembelajaran.

Hasil belajar yang kurang memuaskan seperti tersebut diatas, sejalan dengan hasil evaluasi / tes hasil belajar yang masih rendah. Prosentase ketuntasan klasikal sebesar 73, $12 \%$ menunjukkan masih rendahnya nilai rata-rata dan tingkat ketuntasan siswa dalam memahami materi yang diajarkan. Hasil ini juga memberi makna bahwa hanya 32 orang siswa dari 42 jumlah siswa yang telah tuntas . Sedangkan 10 siswa atau sekitar 26,88\% siswa belum tuntas dalam materi tersebut. 
Adanya berbagai kelemahan dalam pelaksanaan tindakan pada siklus I ini menuntut perlunya perbaikan dan pembuktian kembali pada siklus berikutnya (siklus II). Diperlukan perencanaan kembali untuk kegiatan siklus II dengan mengacu pada identifikasi kelemahan-kelemahan tindakan pada siklus I. Berdasarkan hal di atas, maka beberapa tindakan baru yang dilaksanakan pada siklus II adalah sebagai berikut :

Guru memperjelas kembali aturan main diskusi dengan harapan bahwa siswa mampu memahami secara baik langkah-langkah dalam kegiatan diskusi tersebut.

Agar kegiatan ini dapat efektif dan efisien.Guru memberikan bimbingan langsung kepada individu/kelompok-kelompok yang diidentifikasi memiliki masalah-masalah dengan cara mendatangi individu atau kelompok tersebut (guru tidak hanya memantau dari belakang meja). Dilain pihak individu atau kelompok yang dianggap berhasil dalam melaksanakan tugasnya baik pada kegiatan diskusi kelompok kecil maupun pada saat kegiatan presentasi perlu diberikan reward. Hal ini dapat dilakukan antara lain dengan memberikan aplous, acungan jempol atau cara-cara lain yang dapat menarik perhatian siswa atau mampu membangkitkan semangatnya.

Berbagai tindakan baru yang dilaksanakan pada siklus II ternyata membawa hasil yang cukup baik. Setelah guru kembali melakukan sosialisasi secara singkat berkaitan dengan aturan main, memberikan dorongan/penghargaan kepada individu atau kelompok yang aktif dan bimbingan secara langsung kepada kelompok yang dianggap bermasalah, maka beberapa hal yang dianggap sebagai masalah pada siklus I secara umum telah berhasil diatasi. siswa telah menunjukkan keseriusannya dalam proses pembelajaran. Tingkat keaktifan masing-masing individu dalam kelompok baik pada saat diskusi di kelompok ahli maupun diskusi di kelompok asal sangat tinggi. Tidak terlihat lagi siswa yang lalu lalang tanpa tujuan yang jelas serta waktu yang digunakan oleh masing-masing kelompok sesuai dengan waktu yang sudah ditargetkan. Adanya peningkatan keaktifan siswa dalam mengikuti pembelajaran sebagai hasil dari berbagai perbaikan yang dilakukan oleh guru ternyata sejalan dengan peningkatan prestasi yang dicapai oleh siswa. Nilai rata-rata kelas meningkat dari 70,73 menjadi 74,78. Siswa yang tuntas secara individual meningkat dari 31 menjadi 35 orang siswa atau ketuntasan klasikal meningkat dari 77,50\% menjadi $87,50 \%$ 
Akan tetapi berbagai peningkatan/kemajuan yang dicapai pada siklus II ini ternyata belum dapat memenuhi standar/indikator kinerja ideal seperti yang sudah ditetapkan sebelumnya. Karena itu dilakukan kembali analisa/refleksi terhadap proses pelaksanaan pembelajaran. Hasil refleksi menujukkan bahwa masih ditemukan beberapa kelamahan pelaksanaan tindakan pada siklus II antara lain masih adanya anggota kelompok bermasalah yang belum tersentuh dengan bimbingan individual dari guru, dan kualitas pertanyaan yang masih rendah dari siswa.

Mencermati hasil evaluai seperti yang dipaparkan diatas, maka dapat dijelaskan bahwa probematika yang dihadapi pada siklus II ini sebenarnya mirip dengan apa yang terjadi pada siklus sebelumnya. Belum tercapainya indikator kinerja bukan disebabkan oleh faktor metode atau model pembelajaran yang tidak tepat, melainkan masih belum maksimalnya implementasi metode tersebut dalam pelaksanaan pembelajaran. Karena itu perlu dilanjutkan pada siklus III dengan tindakan-tindakan perbaikan.Ketika ada satu atau dua siswa yang nampak mengalami kesulitan, guru dengan sigap dan penuh semangat berusaha mendekati individu atau kelompok tersebut untuk memberika bimbingan secara langsung.

Sikap yang ditunjukkan oleh guru tersebut ternyata mendapat respon yang sangat positif dari siswa. Mereka merasa sangat diperhatikan oleh gurunya. Indikasi dari respon positif terhadap berbagai perubahan/tindakan-tindakan baru tersebut juga nampak dari Partisipasi siswa dalam setiap rangkaian kegiatan pembelajaran. Hal ini terlihat dari tingkat efisiensi/pemampaatan waktu yang cukup baik oleh masing-masing kelompok dalam menyelesaikan tugas-tugas yang diberikan. Begitu pula halnya dengan kegiatan tanya jawab, yang ditunjukkan tidak hanya dengan tingginya prosentase siswa yang mengajukan pertanyaan atau menanggapi pertanyaan melainkan diikuti dengan meningkatnya kualitas pertanyaan yang diajukan.

Hasil observasi terhadap tingkat keaktifan siswa yang cukup baik ini juga selaras dengan hasil evaluasi terhadap pelaksaanaan pembelajaran. Berdasarkan tes hasil belajar pada siklus III menujukkan adanya peningkatan yang cukup signifikan. Nilai ratarata kelas telah meningkat dari yang sebelumnya sebesar 81,21 meningkat menjadi 85,45 . Begitu pula halnya dengan tingkat ketuntasan siswa yang telah mencapai $100 \%$. 
Meningkatkan Keaktifan.....- Haeruddin

Mengacu pada indikator-indikator di atas, maka dapat dikatakan bahwa penerapan model Jigsaw Plus telah mampu meningkatkan keaktivan siswa kelas XII IPS 3 SMA Negeri 1 Selong dalam mengikuti pembelajaran sejarah. Karena itu kegiatan penelitian ini telah dianggap cukup untuk mampu membuktikan hipotesis tindakan sebelumnya

\section{SIMPULAN}

Penerapan Model Jigsaw Plus dalam pembelajaran Materi Orde Reformasi telah berhasil meningkatkan keaktifan siswa kelas XII IPS 3 SMA Negeri 1 Selong tahun pembelajaran 2017 / 2018dengan rincian hasil sebagai berikut:

Pelaksanaan pembelajaran dengan menerapkan Model Jigsaw Plus pada siklus pertama belum dapat mencapai target sesuai dengan indikator kinerja yang telah ditetapkan. Perosentase ketuntasan baru mencapai 29 dari 33 orang siswa keseluruhan atau sekitar 87,87. Sedangkan nilai rata rata kelas yang dicapai sebesar 77,42. Pada siklus II telah terjadi peningkatan, tetapi belum mencapai indikator kinerja. Ketuntasan individual meningkat menjadi 32 orang siswa atau persentase ketuntasannya mencapai 96,96\%. Begitu pula halnya peningkatan nilai rata-rata dengan capaian sebesar 81,21. Berdasarkan hasil observasi baik terhadap siklus I maupun siklus II diperoleh data bahwa pada pelaksanaan pembelajaran masih banyak terjadi kelemahan, sehingga berpengaruh terhadap hasil belajar siswa. Kelemahan-kelamahan tersebut meliputi rendahnya tingkat pemahaman siswa terhadap aturaan main diskusi, rendahnya tingkat kemampuan guru dalam membangkitkan motivasi belajar dan bimbingan individual kepada siswa yang bermasalah, rendahnya tingkat keaktifan siswa mengikuti kegiatan baik dikelompok asal, kelompok ahli maupun kelompok utama.

Adanya berbagai kelemahan yang muncul pada siklus I dan II telah mampu dijadiklan dasar bagi perbaikan pada siklus berikutnya. Tindakan-tindakan baru yang dilakukan pada siklus II dan siklus III meliputi penegasan kembali terhadap aturan main diskusi, pemberian bimbingan langsung kepada individu/kelompok yang menemui kesulitan atau reward bagi yang berhasil dan pembagian kerja yang lebih riil kepada anggota kelompok, serta arahan terhadap pola penyampaian simpulan. Adanya tindakan-tindakan baru tersebut berpengaruh terhadap proses peningkatan keaktifan dan hasil pembelajaran. Dari hasil evaluasi yang dilakukan nampak bahwa pada siklus 
Meningkatkan Keaktifan.....- Haeruddin

III hasil yang dicapai telah sesuai dengan indikator kinerja. Persentase ketuntasan telah mencapai $100 \%$. Dengan rata-rata kelas sebesar 85,45. Berdasarkan hasil tersebut, maka kegiatan penelitian dianggap cukup untuk membuktikan bahwa pengembangan Model Jigsaw Plustelah mampu meningkatkan keaktifan siswa dalam Pembelajaran Masa Orde Reformasisiswa kelas XII IPS 3 SMAN 1 Selong tahun pelajaran 2017/2018

\section{DAFTAR PUSTAKA}

Arikunto, S., 2010. Prosedur Penelitian, Suatu Pendekatan Praktik. Jakarta: Rineka Cipta

Aqib, Z. 2002. profesionalisme Guru dalam Pembelajaran.Surabaya: Insan Cendekia. Slavin, R.E., 2005. Cooperative Learning, Teori, Riset dan Praktik. diterjemahkan oleh Narulita Yusran. Bandung: Nusa Media

Miles, M. B \& Huberman, A. M. 1992. Analisis Data Kualitatif. Terjemahan Tjejep Rohendi. Jakarta: UI Perss

Isjoni. 2007. Pembelajaran Sejarah Pada Satuan Pendidikan. Bandung: Alpabeta

Silberman, M L. 2004. Aktif Learning; 101 Cara Belajar Siswa Aktif. Terjemahan Raisul Muttaqien. Bandung: Nusamedi 